Dr VLADIMIR KRIVOŠEJEV, naučni saradnik

Narodni muzej Valjevo

Valjevo, Republika Srbija ～～UDK 94:616.9(497.11 Ваљевски крај)"1918/1919"(093.2)

vladimir.krivosejev@gmail.com

originalan naučni rad / original scientific paper

primljeno / received: 14. 6. 2020.

prihvaćeno / accepted: 20. 11. 2020.

https://doi.org/10.29362/ist20veka.2021.1.kri.35-52

\title{
POSLEDICE PANDEMIJE ŠPANSKE GROZNICE U VALJEVSKOM SREZU 1918-1919.
}

APSTRAKT: Zahvatajući skoro celu planetu, pandemija španske groznice 1918/19. godine nije zaobišla ni stanovništvo okupirane Srbije, ni vojnike na Solunskom frontu. Eskalirala je neposredno po proboju fronta, a vrhunac je dostigla u trenucima euforije zbog oslobođenja. Cilj ovoga rada jeste da ukaže na mogući put dolaska i hronologiju razvoja epidemije u Valjevskom srezu, kao i na broj žrtava koje je ona tu odnela. Rezultati analize crkvenih knjiga umrlih, i to na skoro stopostotnom uzorku, ukazuju da je masovno umiranje od posledica epidemije otpočelo tokom druge polovine oktobra u ravničarskim delovima sreza, ali da je tu mortalni udar bio relativno slab. Odatle se epidemija širila na udaljenija i nepristupačnija brdsko-planinska sela, gde je smrtnost bila veoma visoka, u pojedinim naseljima umrlo je više od 9\% stanovništva. Glavni mortalni udar epidemije je trajao do pred kraj 1918. godine, a posle toga se u naseljima gde je prethodno smrtnost bila veća uočavaju slabije posledice u odnosu na naselja gde je bila manja.

KLJUČNE REČI: epidemija 1918, pandemija, španski grip, španska groznica, španska influenca, španska bolest, Prvi svetski rat, Srbija, Valjevo, Valjevski srez

\section{Uvod}

Na samom kraju Prvog svetskog rata skoro ceo svet se suočio sa novom katastrofom, pandemijom španske groznice koja je odnela nebrojene živote. Po svemu sudeći pandemija je počela da se širi iz Sjedinjenih Američkih Država. Preko američkih regruta, koji su se masovno iskrcavali u luci Brest u Francuskoj, virus influence $A$ (H1N1) preplavio je strahovitom brzinom Evropu, a potom i druge kontinente. Dok je ratna cenzura u sukobljenim državama prikrivala informacije o zarazi, mediji u Španiji, koja nije bila učesnik rata, otvorenije su pisali o pojavi bolesti. Tako je stvoreno pogrešno mišljenje da je ova država žarište zaraze, što je dalo ime bolesti. ${ }^{1}$

\footnotetext{
${ }^{1}$ Milorad Radusin, "The Spanish Flu: Part I: the first wave”, Vojnosanitetski pregled, vol. 69, no. 9, (2012), 812-817.
} 
Pandemija je imala tri talasa. Prva dva, blaži prolećno-letnji i jesenji, koji je bio poguban, rasplamsavali su se tokom 1918. godine. Treći, zimski, takođe je ostavio velike posledice širom sveta ali samo na nekim teritorijama, uglavnom onim gde drugi talas nije delovao u punoj pogubnosti. Razvijao se od kraja 1918. i tokom prvih meseci 1919. godine, ali su se njegovi repovi ponegde uočavali do kraja te, pa i tokom naredne 1920. godine. Velika smrtnost izražena u drugom, a delimično i trećem talasu pandemije najčešće je bila uzrokovana dodatnim komplikacijama influence. Oboleli su uglavnom umirali usled naknadno razvijene pneumonije, bilo primarne virusne, bilo sekundarne bakterijske. ${ }^{2}$

Blaži prolećno-letnji talas pandemije je stigao i do teritorije okupirane Srbije i do vojnika na Solunskom frontu, ali nije ostavio velike posledice, bar ne $\mathrm{u}$ onakvoj meri koliko je to učinio jesenji talas, koji se takođe uočava na obe teritorije. O masovnosti zaraze tokom drugog talasa svedoči telegram koji je 13/26. oktobra 1918, pre okončanja borbi za oslobođenje, komandant Prve armije Petar Bojović poslao iz Kragujevca Vrhovnoj komandi u kojem naglašava da nema svrhe da se uvode bilo kakve karantinske mere ,jer se radi o bolesti od koje i onako boluje cela armija i stanovništvo“. 3

Epidemija je vrhunac dostigla u trenucima oslobađanja Srbije, kada je dolazak obolelih vojnika među već obolelo stanovništvo povećao koncentraciju virusa, što je doprinelo da za kraće vreme oboli veći broj ljudi. Na to su morali uticati javni skupovi organizovani povodom pobede, kao i odsustva i demobilizacija vojnika.

\section{Posledice pandemije u Trsteničkom, Zlatiborskom i Kameničkom srezu}

Za razliku od velike epidemije tri tifusa sa samog kraja 1914. i prve polovine 1915. godine, o naletu španske groznice 1918. godine, a naročito o njenim posledicama, danas se relativno malo zna, ali je poznato da je u Trsteničkom srezu ona bila pogubnija od tifusa. Dok je tifus odneo 875 života meštana, od španske groznice je umrlo 1.267 stanovnika sreza, ${ }^{4}$ što ukazuje da je od ove epidemije umrlo 3,74\% stanovništva u odnosu na broj popisanih 1916, kao i da je za dva meseca trajanja epidemija španske groznice učestvovala u ukupnom šestogodišnjem direktnom ratnom gubitku sa 39,38\% ${ }^{5}$ Još veća stopa smrtnosti je zabeležena u planinskom Zlatiborskom srezu gde je na teritoriji 12 sela, za koje postoje raspoloživi podaci, od 16 sela koliko je srez imao, umrlo 775 ljudi, ${ }^{6}$

\footnotetext{
${ }^{2}$ Milorad Radusin, "The Spanish Flu: Part I“ i „The Spanish Flu: Part II: the second and third wave", Vojnosanitetski pregled, vol. 69, no.10, (2012), 917-922.

3 Alfred Nik, „Historiografija vojnog saniteta Jugoslovenskih zemalja, II dio: 1912-1919”, Acta historica Medicinae, Pharmaciae, Veterinae, vol. X, no. 1-2, (1969), 219-239.

4 Тома Миленковић, Трстеник и околина у Првом светском рату 1914-1918 (Београд: Институт за савремену историју, 2007), 161-162.

${ }^{5} \mathrm{U}$ srezu je 1910. popisano 38.846 stanovnika, 1916. godine 33.914, a 1921. godine 35.629. T. Миленковић, н. д., 149.

${ }^{6}$ Милисав Ђенић, „Епидемије тифуса и шпанске грознице на Златибору у време Првог светског рата“, Ужички зборник, 14, (1985), 156.
} 
što navodi na pretpostavku da je u celom srezu umrlo više od 1.000 ljudi, odnosno oko 5\% stanovništva, te da je učešće španske groznice u ukupnim direktnim ratnim gubicima bilo oko $18 \%{ }^{7}$

Za razliku od Zlatiborskog sreza, sa izrazito brdsko-planinskim ruralnim okruženjem, delimično dolinski, delimično brdsko-planinski Trstenički srez je imao dva varoška centra, Trstenik i Vrnjačku Banju. Na prvi pogled zvuči paradoksalno činjenica da su skoro svi umrli bili iz ruralnih teritorija, dok je broj preminulih $\mathrm{u}$ urbanizovanim centrima sreza bio minimalan: dvoje u Trsteniku i jedno u Banji. ${ }^{8}$ Sa druge strane istraživanja koja su prethodila ovom radu ukazuju da su na teritoriji 17 brdsko-planinskih sela Kameničkog sreza od posledica španskog gripa umrle 483 osobe, odnosno 4,25\% stanovništva, što je nešto manje nego u planinskom Zlatiborskom, ili više nego u Trsteničkom srezu, sa dva urbanizovana centra. Budući da se Kamenički srez sastojao od 27 sela u kojima su 1916. godine živela 11.374 stanovnika, a da raspoloživi uzorak od 17 sela predstavlja $63 \%$ naselja i 56\% stanovništva, može se pretpostaviti da je španska groznica na teritoriji celog sreza odnela oko 900 života, odnosno oko $4,5 \%$ stanovništva, što bi predstavljalo oko $20 \%$ ukupnih direktnih ratnih gubitaka za svih šest godina ratovanja. ${ }^{9}$

Kamenički srez je bio jedan od pet srezova Valjevskog okruga koji je prema popisu iz 1910. imao 157.648, a šest godina kasnije 117.502 žitelja. $^{10}$ Prema popisu sa početka 1921. godine okrug je imao 133.974 stanovnika, ${ }^{11}$ za $23.674(15,02 \%)$ manje nego 1910, ali usled povratka vojnika i interniraca za $16.472(14,02 \%)$ više nego 1916 . godine.

\section{Posledice pandemije u Valjevskom srezu}

Najveći srez u Valjevskom okrugu bio je Valjevski. On se sastojao od 14 opština sa 52 naseljena mesta. Sama varoš Valjevo se nalazi u kotlini, na početku kolubarske doline, koja se proteže na severoistok, ka Beogradu. Severno od Valjeva se prostiru blaga pobrđa koja valjevski kraj odvajaju od ravne Mačve, a južno i zapadno brdsko-planinski predeli na obroncima valjevskih planina. Prema popisu iz 1910. u srezu je živelo $36.867,1916$. godine $27.746{ }^{12}$ a 1921. popisano je 33.600 stanovnika. ${ }^{13}$

\footnotetext{
7 U srezu je 1910. popisano 25.797 stanovnika, 1916. godine 20.435, a 1921. godine 21.164. Љубодраг Поповић, „Прилози за историју ужичког краја у Првом светском рату: губици у становништву од 1912-1918“, Ужсики зборник, 14, (1985), 137-150.

${ }^{8}$ Т. Миленковић, н. д., 161-162.

${ }^{9}$ Popisom iz 1910. godine registrovano je 26.524 stanovnika, a 1921. godine 22.001. Владимир Кривошејев, „Прилог проучавању пандемије шпанске грознице у селима ваљевског краја“, Гласник Историјског архива Ваљево, 54, (2020), 61-97.

10 Љубодраг Поповић, „Попис становништва Ваљевског округа у І светском рату“, Гласник Историјског архива Ваљево, 34, (2000), 159-170.

${ }^{11}$ Дефинитивни резултати пописа становништва од 31. јануара 1921 (Сарајево: Државна штампарија, 1932), 8-13.

12 љ. Поповић, „Попис становништва Ваљевског округа у І светском рату“, 159-170.

${ }^{13}$ Дефинитивни резултати пописа становниттва од 31. јануара 1921, 8-13.
} 
Dejstvo španske groznice u valjevskom kraju je jezgrovito, u nekoliko rečenica, opisala Perka Spasenić: „Pre nego što su naši trebali da dođu zavladala je španska groznica u tolikoj meri da je po troje - četvoro u kući umiralo od nje, pa i cela porodica. Leka nema. Švabe se povlače. Dotle su nas njihovi lekari svesrdno lečili. Ja sam išla u apoteku da pitam šta da radim sa komšilukom. Oni mi kažu: samo čorba, crno vino, lipov čaj i aspirin. (...) U pojedinim kućama je španska groznica trajala po celu zimu. Počela je u leto 1918. godine i oni koji su je prvi dobili prolazili su bolje jer su jeli lubenice i prali glavu hladnom vodom. Obično se krv otvarala na nos i onda je bivalo lakše, temperatura spada. Onima kojima se nije krv otvorila, obično je silazilo u pluća i oni su umirali ili odmah ili kasnije, pa čak i u proleće od tuberkuloze“. ${ }^{14}$

Iako su u navedenom citatu naglašene sve ključne faze razvoja pandemije, od prve, benignije pojave, preko udarnog mortalnog talasa, do delovanja naknadnih „repova“, nemamo informacije o broju preminulih. Glavni istorijski izvori koji omogućavaju da se dođe do ovih podataka jesu crkvene knjige umrlih, ali pri njihovoj analizi mora da se povede računa o razlikama u državnoj i crkvenoj administraciji, budući da su se pojedina sela koja su pripadala jednoj crkvenoj parohiji nalazila ne samo u sklopu različitih sreskih opština, već i različitih srezova.

U ovom članku su analizirane smrtne posledice od pandemije španske groznice registrovane $u$ deset knjiga umrlih iz crkava kojima je gravitiralo 51 naselje Valjevskog sreza. Od 52 sreska naselja jedino nedostaju podaci za Slovac, koji je verovatno gravitirao nekoj od parohija iz Ubskog sreza. To je inače bilo selo sa 278 stanovnika, što je predstavljalo oko 1\% stanovništva sreza, tako da je obrađeni uzorak skoro stopostotni.

\section{Upisi u knjigu umrlih valjevske parohije}

Parohiji valjevske crkve pripadalo je Valjevo sa privaroškim zaseocima i sela: Grabovica, Rađevo Selo, Jasenice i Degurić, s tim što su u njenoj knjizi umrlih ${ }^{15}$ upisivane i smrti stanovnika drugih naselja iz sreza, okruga i relativno udaljenijih mesta, koji su umrli u varoši, najčešće u okružnoj bolnici, i iz različitih razloga sahranjivani na varoškim grobljima. Tokom cele 1918. godine registrovana su ukupno 342 umrla, od čega 167 u poslednja 3 meseca, tokom kojih je harao mortalni udar epidemije. ${ }^{16}$ Oko 50\% upokojenih je umrlo u bolnici, a ostali kod svojih kuća. Kako je već naglašeno fatalna komplikacija španske groznice je bilo zapaljenje pluća, odnosno pneumonija i ona je u mnogim slučajevima registrovana kao uzrok smrti.

Tokom leta 1918. godine, u vreme prvog talasa pandemije, u knjizi umrlih se povremeno kao uzrok smrti pojedinaca upisuje ,zapaljenje pluća“,

14 Љубица Трајковић, Казивања о старом Ваљеву (Ваљево: приватно издање Драгољуба Трајковића, 1980), 73.

${ }^{15}$ Grad Valjevo, matičarska služba: Кюига иркве ваљевске, храма Покрова Свете Богородиие, за уписивағе умрлих, за 1915-1923. годину.

${ }^{16}$ Po numeraciji rubrika u celoj godini su umrle 334 osobe, a u poslednja tri meseca 159 , međutim brojevi rubrika od 273 do 280 , u kojima su registrovana umiranja tokom novembra, ponavljaju se na dve uzastopne strane. 
ako su umrli kod svoje kuće, odnosno ,pneumonija“, ali i „,apicitis“, ${ }^{17}$ ako su preminuli u bolnici, da bi se tokom septembra broj umrlih sa takvom dijagnozom blago povećao, ali masovno umiranje počinje narednog meseca, konkretno 7/20. oktobra. Toga dana je u selu Jasenice umrla jedna osoba kojoj je kao uzrok smrti upisana ,španska groznica“, a u varoškom zaseoku Gradac, selu Grabovica i Valjevu umrla je po jedna osoba od ,zapaljenja pluća“. Narednog dana umire jedna osoba od „sipnje“"18 i još jedna od ,španske groznice“, i od tada umiranje sa tom dijagnozom postaje masovno i svakodnevno. Za umrle kod svojih kuća preovlađuje upis ,„spanska groznica“, a za u početku retke preminule u bolnici upisuje se ,pneumonija“. Međutim, posle oslobođenja Valjeva, 17/30. oktobra, ${ }^{19}$ stanje se menja.

Kako je naglašeno, Perka Spasenić se sećala da su narod u okupiranom Valjevu „svesrdno“ lečili austrougarski lekari, ali da se oni sa okupacionom vojskom povlače upravo u vreme izbijanja epidemije. Dolaskom srpske vojske uspostavljen je stabilniji rad okružne bolnice, a zbog epidemije su njeni kapaciteti prošireni, verovatno za pacijente sa epidemijskim simptomima. ${ }^{20}$ Zato, već pre sredine novembra sve veći broj ljudi umire u bolnici, i za njih se kao uzrok smrti skoro isključivo upisuje ,pneumonija“, po svemu sudeći na osnovu lekarskog nalaza, mada se povremeno i dalje nailazi na upis ,španska groznica“, ali uglavnom za pojedince umrle kod svojih kuća.

Masovnije umiranje izazvano epidemijom trajalo je do 10/23. decembra, a potom postaje sporadično. Jedna smrt od španske groznice je upisana i 30 . decembra (12. januara 1919), a druga 19. januara / 1. februara. Dalje se povremeno javlja umiranje usled zapaljenja pluća, s tim što je tokom marta bilo nešto učestalije. Od početka 1919. godine do početka aprila registrovano je ukupno 36 smrti, od toga, pored pomenutih od španske groznice, 11 je bilo usled zapaljenja pluća, a 8 od tuberkuloze.

Od početka masovnog umiranja 7/20. oktobra do poslednje smrti kojoj je kao uzrok upisana ,španska groznica“ registrovano je ukupno 167 smrtnih slučajeva, među kojima 13 od tuberkuloze, 38 od španske groznice a 84 od zapaljenja pluća. Ako pretpostavimo da je apsolutna većina umrlih od zapaljenja pluća bila obolela od španskog gripa, mogli bismo da zaključimo da su u Valjevu od posledica epidemije umrle 122 osobe. $^{21}$ Kao što je naglašeno, nisu svi

\footnotetext{
${ }^{17}$ Zapaljenje vrhova pluća. Inače, vrhovi pluća su često zahvaćeni kod tuberkuloze, pa je možda takav uzrok smrti upisivan kod onih koji su takođe od nje bolovali.

${ }^{18}$ Stari narodni izraz za astmu.

${ }^{19}$ Владимир Кривошејев, Ослобођење Ваљева у Великом рату 30. октобра 1918 (Ваљево: Књижевни клуб Ваљева, 2018).

${ }^{20}$ Prema izjavi Dragomira Vitorovića iz Dupljaja, datoj autoru 31. maja 2020, njegov deda Živorad Vitorović se neposredno po završetku rata vratio iz internacije u Nemačkoj i u Dupljaju je oboleo od španske groznice. Dopremljen je u Valjevo i izlečen u bolnici koja se privremeno nalazila $u$ zgradi današnjeg Okružnog suda, a bolesnici su bili smešteni i u zgradi Opštinskog suda.

${ }^{21}$ To ukazuje na mogućnost da je i u Trsteniku i Vrnjačkoj Banji moglo biti više smrtnih slučajeva usled posledica pandemije, ali da zbog drugog upisanog uzroka (zapaljenje pluća) njihova smrt nije prepoznata kao posledica pandemije (?).
} 
umrli bili meštani Valjeva i naselja koja gravitiraju parohiji valjevske crkve. Iz same parohije je od posledica epidemije umrlo 39 osoba, odnosno $0,79 \%$ stanovnika u odnosu na broj iz popisa vršenog 1916. godine. Razlika u smrtnosti između naselja bila je relativno velika. Iz same varoši je umrlo $0,68 \%$ stanovništva, a iz sela Jasenice 2,76\%.

\begin{tabular}{|l|c|c|c|c|c|}
\hline UMRLI IZ NASELJA & $\begin{array}{c}\text { Broj } \\
\text { stanovnika } \\
1916 .\end{array}$ & $\begin{array}{c}\text { Umrli od } \\
\text { zapaljenja } \\
\text { pluća }\end{array}$ & $\begin{array}{c}\text { Umrli od } \\
\text { španske } \\
\text { groznice }\end{array}$ & Ukupno & $\begin{array}{c}\text { \% umrlih u } \\
\text { odnosu na } \\
\text { broj sta- } \\
\text { novnika }\end{array}$ \\
\hline Valjevo & 5.698 & 21 & 18 & $\mathbf{3 9}$ & $0,68 \%$ \\
\hline Grabovica & 710 & 1 & 2 & $\mathbf{3}$ & $0,42 \%$ \\
\hline Rađevo Selo & 428 & 4 & 2 & $\mathbf{6}$ & $1,40 \%$ \\
\hline Jasenice & 290 & 2 & 6 & $\mathbf{8}$ & $2,76 \%$ \\
\hline Degurić & 255 & 2 & 0 & $\mathbf{2}$ & $0,78 \%$ \\
\hline \multicolumn{1}{|c|}{ Ukupno } & $\mathbf{7 . 3 8 1}$ & $\mathbf{3 0}$ & $\mathbf{2 8}$ & $\mathbf{5 8}$ & $\mathbf{0 , 7 9 \%}$ \\
\hline $\begin{array}{l}\text { Iz sela Valjevskog } \\
\text { sreza, van valjevske } \\
\text { parohije }\end{array}$ & 13 & 2 & 15 & \\
\hline $\begin{array}{l}\text { Iz sela Kameničkog } \\
\text { sreza }\end{array}$ & & 8 & 2 & 10 & \\
\hline $\begin{array}{l}\text { Iz sela Mioničkog } \\
\text { sreza }\end{array}$ & & 2 & 1 & 3 & \\
\hline $\begin{array}{l}\text { Iz sela Tamnavskog } \\
\text { sreza }\end{array}$ & & $\mathbf{2 9}$ & $\mathbf{5}$ & $\mathbf{3 4}$ & \\
\hline Ukupno & $\mathbf{2 5}$ & $\mathbf{5}$ & $\mathbf{3 0}$ & \\
\hline $\begin{array}{l}\text { Van teritorije Valjev- } \\
\text { skog okruga }\end{array}$ & & $\mathbf{8 4}$ & $\mathbf{3 8}$ & $\mathbf{1 2 2}$ & \\
\hline Ukupno & & 0 & 6 & \\
\hline
\end{tabular}

Broj umrlih od španske groznice na teritoriji valjevske parohije

Za razliku od Valjeva, gde su mnogi oboleli umirali u bolnici pa je u knjige umrlih upisivan uzrok naveden u službenoj, lekarskoj potvrdi o smrti, u selima su ljudi uglavnom bolovali i umirali kod svojih kuća, a da lekara nisu ni videli. Tada su lokalni sveštenici samostalno procenjivali uzroke smrti, upisujući naziv osnovne epidemijske bolesti, pa i kada upokojeni umru od njene fatalne komplikacije - zapaljenja pluća, tako da se retko uočava dvojnost upisa uzroka kao u varoši. Neophodno je naglasiti da različiti sveštenici epidemijsku bolest različito imenuju. Dok većina upisuje „španska groznica“ ili „španska bolest“, a drugi pišu „zarazna influenca“, sveštenik u Jovanji dosledno upisuje „zapaljenje pluća“, a sveštenik u Pričeviću „tifusna groznica“. ${ }^{22}$

${ }^{22}$ Većina sela pričevićke parohije pripadala je Kameničkom srezu, osim Balinovića, koji je pripadao Valjevskom srezu (Владимир Кривошејев, Јелена Кривошејев и Ален Радосављевић, „Смртне последице епидемије шпанске грознице 1918. године у Каменичком срезу ваљевског округа“, rad poslat 25. aprila 2020. uredništvu Vojnoistorijskog časopisa; recenzentski prihvaćen). S druge strane sveštenik u Krčmaru, iz kolubarskog i mioničkog sreza, dosledno koristi pojam „tifus“ (Владимир Кривошејев, „Смрт у Крчмару: прилог квантификацији жртава пандемије шпанског грипа 1918. године“, Етноантрополошки проблеми, вол. 15, св. 2/2020, 601-626). Imajući u vidu 


\section{Upisi u knjige umrlih seoskih parohija bliže Valjevu}

Parohija crkve u Jovanji se nalazi zapadno i jugozapadno od varoši Valjevo na teritoriji sa pobrđem. Jovanja je faktički zaselak sela Zlatarić, nazvan po crkvi posvećenoj Svetom Jovanu. Mada kao naselje nije postojala, po njoj je nazvana i sreska opština kojoj su pripadala četiri sela: Zlatarić, Paklje, Sedlari i Balinović. U crkvene knjige crkve u Jovanji su upisivani meštani sela: Zlatarić, Sedlari, Paklje i Sandalj, ali i iz manjeg dela sela Stubo, koje je pripadalo lelićkoj opštini, a većinski gračaničkoj parohiji, verovatno iz onog dela koji je zalazio u atar sela Paklje. Sandalj je pripadao drugoj opštini Valjevskog sreza, lelićkoj, a Balinović, iako u opštini Jovanja, prema crkvenoj administraciji je pripadao crkvi u Pričeviću, čija je parohija većinski gravitirala Kameničkom srezu.

U knjizi umrlih crkve u Jovanji ${ }^{23}$ tokom cele 1918. godine registrovana su 54 upisa, od čega 35 u poslednja tri meseca. Tokom letnjih meseci smrtnost je bila uobičajena da bi 29. septembra (12. oktobar) u Zlatariću umrla jedna osoba od zapaljenja pluća, a onda, desetak dana posle Valjeva, od 17/30. oktobra počinje masovnije umiranje i traje do decembra. Tokom tog perioda tamošnji sveštenik za sve umrle od posledica epidemije koristi pojam zapaljenje pluća, a tek znatno kasnije, početkom 1919, naknadno upisuje smrt jednog meštanina Sedlara, koji je 29. septembra (12. oktobra) preminuo u Bogovađi, od „španske groznice“. Sa tom osobom pandemija je odnela 29 žrtava, a smrtnost se razlikovala od sela do sela. U selima bliže Valjevu, Sedlarima i Zlatariću, umrlo je 1,34\%, odnosno 1,36\% stanovništva, a u Pakljama 4,60\%, dok iz Sandalja nema registrovanih umrlih od posledica epidemije, ali su upisane i 2 osobe preminule u Stubu. ${ }^{24}$

\begin{tabular}{|l|l|l|l|}
\hline & $\begin{array}{l}\text { Broj stanovnika } \\
1916 .\end{array}$ & $\begin{array}{l}\text { Broj umrlih od } \\
\text { španske groznice } 25\end{array}$ & $\%$ \\
\hline Zlatarić & 879 & 12 & $1,36 \%$ \\
\hline Sedlari & 502 & 7 & $1,34 \%$ \\
\hline Paklje & 174 & 8 & $4,60 \%$ \\
\hline Sandalj & 163 & 0 & $0,00 \%$ \\
\hline Ukupno & $\mathbf{1 . 7 1 8}$ & $\mathbf{2 7}$ & $\mathbf{1 , 5 7 \%}$ \\
\hline
\end{tabular}

Broj umrlih od španske groznice na teritoriji jovanjske parohije

doslednost sveštenika u takvim imenovanjima (zapaljenje pluća, tifusna groznica, tifus) uzroka smrti do kojih dolazi u isto vreme i podjednako masovno kao i do smrti u susednim mestima čiji je uzrok imenovan nazivom koji eksplicitno ukazuje na aktuelnu pandemiju, ne bi trebalo da bude sumnje da su i ovi pokojnici bili njene žrtve, s tim što crkveni administratori ranije nepoznatu bolest, za koju se koriste do tada nepoznati pojmovi, imenuju po svome, koristeći njima od ranije poznate termine.

${ }^{23} \mathrm{Grad}$ Valjevo, matičarska služba: Книга иркве јованске, храма Рођења Светог Јована, за уписивање умрлих, за 1902-1930. годину. Do polovine septembra upisi su vođeni datumski dvojno 11/24. avgust; 5/18. septembra i sl., a potom (posle proboja Solunskog fronta?!) samo jednodatumski (julijanski?).

24 Time je, uz upisane u crkvenu knjigu Gračanice, broj umrlih iz ovoga sela povećan na 34, odnosno na $6,84 \%$. В. Кривошејев, „Прилог проучавању пандемије...”.

${ }^{25}$ Tamošnji sveštenik za umrle u jeku pandemije ne koristi naziv nove bolesti već dosledno piše „zapaljenje pluća“. 
U dve pomenute parohije, valjevskoj i jovanjskoj, prema popisu iz 1916. godine u 9 naselja živelo je 9.099 žitelja, odnosno 32,79\% stanovnika Valjevskog sreza, dok je preostalih $66,21 \%$ bilo iz ostala 43 naselja, od kojih se jedan deo severno od varoši nalazio na blagom pobrđu ka Mačvi, drugi istočni deo je bio većinski dolinski, a preostala mesta su uglavnom bila brdskoplaninska. Posledice španske groznice u njima su obrađene u posebnom radu i zato će dalje biti predstavljeni samo sumarni rezultati analiza. ${ }^{26}$

Severno od valjevske parohije, na blagom pobrđu koje razdvaja valjevski kraj od ravne Mačve, sa dobrim komunikacijama sa Valjevom, a na putu koji ga povezuje sa Šapcem, nalazi se teritorija parohije crkve u Brankovini. Nju čini 8 sela Valjevskog sreza: Brankovina, Zabrdica, Blizonje, Joševa, Babina Luka, Kozličić, Kotešica i Rabas. Tokom prvih devet meseci 1918. godine u knjizi umrlih ${ }^{27}$ upisan je 31 smrtni slučaj a u naredna tri meseca je umrla još 61 osoba, što ukazuje na relativno sličnu, mada nešto manju smrtnost nego u jovanjskoj parohiji. Sveštenici ove parohije su epidemijsku bolest u početku imenovali kao zarazna influenca, a potom kao španska groznica. ${ }^{28}$ Prvi smrtni slučaj od ,zarazne influence“ registrovan je 3/16. oktobra u Joševi, gde je zabeležen i drugi šest dana kasnije, a masovno umiranje počinje 17/30. oktobra, desetak dana posle Valjeva i igrom slučaja istovremeno kada i u Jovanji. Masovno umiranje se završava 5/18. decembra, a potom se sreću sporadični smrtni slučajevi. Od zarazne influence, odnosno španske groznice umrlo je 48 ljudi, što je predstavljalo 1,32\% stanovništva. U samoj Brankovini i u Rabasu umrla je po jedna osoba, u Babinoj Luci 15, a u Kotešici 18.

Istočno od brankovačke a severoistočno od valjevske parohije nalazila se parohija crkve u Rabrovici, koja je bila zaselak sela Divci. To je većinski dolinski kraj, sa blagim pobrđem, u dolini Kolubare, duž puta i pruge koji spajaju Valjevo sa Beogradom. Njenoj crkvi je gravitiralo sedam sela: Divci, Klanica, Loznica, Veselinovac, Lukavac, Dupljaj i Popučke. U crkvenoj knjizi umr$\operatorname{lih}^{29}$ tokom 1918. godine registrovano je 77 smrtnih slučajeva, od toga $31 \mathrm{u}$ poslednja tri meseca, što ukazuje da su ovde posledice epidemije bile relativno slabije. Masovno umiranje od ,zarazne influence“, kako pandemijsku bolest imenuje ovdašnji sveštenik, počelo je 24. septembra (7. oktobar), više od tri nedelje pre početka masovnog umiranja u jovanjskoj i brankovačkoj parohiji i dve nedelje pre Valjeva. A bilo je to i 12 dana pre nego što je Natalija Aranđelović 6/19. oktobra u svoj dnevnik upisala da u Beogradu već uveliko ,grdan svet umire“. ${ }^{30}$ Masovno umiranje se naglo prekida 29. novembra (12. decembra). Nepun mesec kasnije, od 27. decembra (9. januara), uočava se relativno

\footnotetext{
${ }^{26}$ Prema: В. Кривошејев, „Прилог проучавању пандемије...”.

${ }^{27}$ Istorijski arhiv Valjevo, digitalizovana građa (IAV, DG): Къига иркве бранковинске храма Светих Арханђела, за уписивање умрлих, за 1917-1921. годину.

${ }^{28}$ Prvonavedeni pojam koristi rabrovički paroh Lukić, koji privremeno administrira brankovačkom parohijom u odsustvu tamošnjih sveštenika, ali kada su se sredinom novembra iz logora u Nežideru vratili sveštenici Svetozar Petrović i Čedomir Vićentijević, oni koriste drugonavedeni pojam.

${ }^{29}$ IAV, DG: Кьига иркве рабровичке (Дивии) храма Светог Оиа Николе, за уписивање умрлих, ва 1915-1935. годину.

${ }^{30}$ Наталија Аранђеловић, Дневник 1915-1918 (Београд: Историјски архив Београда, 2018), 412.
} 
povećana smrtnost koja je do kraja marta odnela živote 13 osoba, uglavnom usled zapaljenja pluća, a nešto manje od ,jektike“" 31

Tokom udarnog talasa u poslednjim mesecima 1918. godine od zarazne influence je umrlo 20 ljudi, odnosno $0,49 \%$ stanovništva sela rabrovičke parohije, mada bi te brojke i procenti mogli da se uvećaju bar za deo od devet osoba umrlih od zapaljenja pluća, ako ne i za sve njih. Ali i sa tim upokojenim rabrovička parohija je teritorija sa najmanjim posledicama pandemije u valjevskom kraju, ali i teritorija na kojoj je masovnije umiranje prvo uočeno. ${ }^{32}$

Istočno od Valjeva, sa direktnom vezom sa varoši, a južno od rabrovičke parohije, na blagom pobrđu severno od venca valjevskih planina, nalazi se pet sela koja su pripadala parohiji crkve u Petnici: Petnica, Beloševac, Bujačić, Klinci i Žabari. Tu je za prvih devet meseci 1918. registrovan 21 pokojnik a u naredna tri meseca $35,{ }^{33}$ što ukazuje na nešto veću smrtnost nego u prethodno navedenim parohijama. Za razliku od drugih parohija, ovde je masovno umiranje počelo znatno kasnije, 2/15. novembra. Na početku je bilo masovnije nego u Rabrovici, pa i Brankovini, ali je trajalo znatno kraće, samo dvadesetak dana, do 22 . novembra/5. decembra. Potom je usledila pauza od desetak dana, da bi 2/15. decembra bio registrovan još jedan smrtni slučaj, pa posle pauze od petnaestak dana, 18. i 19. decembra (31. decembra i 1. januara) i nova dva smrtna slučaja od španske groznice. Tokom narednih zimskih meseci opao je broj smrtnih slučajeva, s tim što je umiranja bilo od tuberkuloze i zapaljenja pluća, ali su registrovane i dve smrti od španske groznice. Od posledica pandemije na teritoriji pet sela ove parohije umrlo je ukupno 25 ljudi, odnosno 1,62\% stanovništva po popisu iz 1916 . godine. Generalno posmatrano, smrtnost je i ovde bila slična kao u drugim selima iz prvog kruga oko Valjeva, s tim što opšti prosek podiže Petnica, gde je umrlo 4,79\% stanovništva, dok je u drugim selima smrtnost bila od 0,57\% do 1,62\%.

Sa ovom parohijom predstavljena su stanja uočena u samom Valjevu i u selima koja ga okružuju, koja su pristupačna i sa dobrim komunikacijskim vezama sa varoši. Dalje sledi prikaz posledica pandemije u zabačenijim, brdskoplaninskim parohijama, u kojima je smrtnost bila znatno veća.

\section{Upisi u knjige umrlih seoskih parohija dalje od Valjeva}

Jedna od parohija sa brdsko-planinskog područja Valjevskog sreza je dračićka, s tim što su sela Dračić i Belić bliža i pristupačniji varoši. Njoj još pripadaju sela: Ravnje, Zarube, Bačevci, Brangović, Kovačice i Prijezdić. U

\footnotetext{
${ }^{31}$ Jektika ili jeftika, stari narodni naziv za tuberkulozu.

${ }^{32}$ Ove informacije, kao i druge slične, treba prihvatiti sa izvesnim ogradama. Neophodno je naglasiti da su po sećanju Snežane Simeunović iz Mionice (izjava data autoru 30. maja 2020), kako joj je pričala baba, od nekakve „strane bolesti“, a koja bi mogla biti španska groznica, umrli njeni pradeda i prababa Rajko i Jelka Petronijević, kao i njihov najstariji sin i snaja, svi iz Lukavca. Međutim, njih nema upisanih u rabrovičkoj knjizi umrlih tokom cele 1918. i 1919. godine, kao ni u knjizi umrlih u Valjevu (!?).

33 IAV, DG: Кьига иркве петничке, храма Успења Пресвете Богородице, за уписивање умрлих, за 1916-1935. годину.
} 
ovoj parohiji je u knjigu umrlih ${ }^{34}$ tokom 1918. godine upisano 113 osoba, a od toga 83 tokom poslednja tri meseca, što ukazuje na znatno veću smrtnost $u$ vremenu trajanja pandemije nego u prethodno prezentovanim parohijama. Posle prvih sumnjivih smrti na prelazu septembra i oktobra meseca masovno umiranje sa uzrokom „španska groznica“ odnosno „španska bolest“, kako naizmenično upisuje tamošnji sveštenik, počelo je nešto ranije nego u većini drugih parohija, ali posle Rabrovice i Valjeva, 11/24. oktobra, ali se i završilo nešto ranije, 25. novembra (8. decembra). Od španske groznice umrle su ukupno 73 osobe, odnosno 3,10\% stanovništva. Najviše je umrlo u mnogoljudnim Bačevcima, 28, a procentualno najviše u Brangoviću, 5,05\%. Najmanje je umrlo u selima koja su najbliža Valjevu, sa kojim imaju relativno dobre komunikacije: po dvoje u Beliću i Dračiću.

U brdsko-planinskim predelima se nalaze i parohije manastira Ćelije i crkve u Gračanici. Ćelijskoj parohiji pripadaju sela: Lelić, Leskovice Gornje i Donje, Bogatić, Sušica i Strmna Gora. U njenoj knjizi umrlih je tokom cele 1918. godine registrovano 216 upisa, a od toga 168 od 26. oktobra (8. novembar). ${ }^{35}$ Tokom prvih meseci 1919. godine uočava se nekoliko smrti usled zapaljenja pluća i ,jeftike“, kao i jedna smrt od „španske groznice“. Od početka pandemije pa do upisa tog smrtnog slučaja španska groznica je odnela živote 156 seljana, odnosno 4,66\% živućeg stanovništva.

U parohiji crkve u Gračanici smrtnost je bila još veća. ${ }^{36}$ Ovde je masovno umiranje počelo $18 / 31$. oktobra i trajalo do $16 / 29$. decembra, da bi desetak dana kasnije bile registrovane dve smrti usled, ,jektike posle španske groznice“. Potom, tokom prvih stotinak dana 1919. registrovano je ukupno 15 smrtnih slučajeva, a od toga dva od španske groznice (tokom januara), dva od zapaljenja pluća i pet od ,jektike“. Ukupno su registrovane 144 osobe umrle od španskog gripa, odnosno 6,17\% stanovništva. Najmanje, 4,58\% stanovnika je umrlo u Kunicama a najviše $9,09 \%$ u Brezovici.

Gračaničkoj parohiji je gravitiralo šest sela sa relativno zabačenog brdsko-planinskog područja od kojih je pet pripadalo Valjevskom srezu: Stubo, Tubravić, Kunice, Brezovica i Rovni, dok su Sitarice pripadale Kameničkom srezu. Slično je bilo sa takođe zabačenim selima drugih parohija, koja su delom pripadala Valjevskom a delom Kameničkom srezu. Valjevskom srezu su još pripadala sela Rebelj, Vujinovača i Sovač iz parohije manastira Pustinja, ${ }^{37}$ kao i Balinović iz parohije crkve u Pričeviću. ${ }^{38} \mathrm{I}$ u ovim zabačenim selima smrtnost je

${ }^{34}$ IAV, DG: Књига иркве драчићке, храма Светих Апостола за уписивағе умрлих, за 19071925. годину.

${ }^{35}$ IAV, DG: Књига иркве ћелијске (Лелић), храма Арханђела Михаила, за уписивање умрлих, за 1903-1921. годину.

${ }^{36}$ IAV, DG: Кьига иркве грачаничке (Поћута), храма Светог Арханђела Михаила, за уписивање умрлих, за 1911-1928. годину.

${ }^{37}$ IAV, DG: Кьига иркве пустињске (Поћута), храма Светог Ваведенија, за уписивање умрлих, за 1911-1924. годину.

${ }^{38}$ IAV, DG: Књига иркве причевачке, храма Светога оца Николаја, за уписивање умрлих, за 1915-1934. годину. 
bila veoma visoka. U Sovču je umrlo devet ljudi $(2,47 \%)$, Vujinovači 12 (3,33\%), Balinoviću 14 (6\%), a u Rebelju 39 osoba (7,89\%).

\begin{tabular}{|c|c|c|c|}
\hline $\begin{array}{c}\text { NASELJA } \\
\text { po opštinama, sa parohijom } \\
\text { kojoj pripadaju }\end{array}$ & $\begin{array}{c}\text { BROJ } \\
\text { STANOVNIKA } \\
\text { po popisu iz } \\
1916 . \\
\end{array}$ & $\begin{array}{c}\text { BROJ } \\
\text { UMRLIH OD } \\
\text { ŠPANSKE } \\
\text { GROZNICE }^{39} \\
\end{array}$ & $\%$ \\
\hline \multicolumn{4}{|l|}{ VAROŠ VALJEVO } \\
\hline $\begin{array}{l}\text { Valjevo } \\
\text { parohija Valjevo }\end{array}$ & 5.698 & 39 & $0,68 \%$ \\
\hline \multicolumn{4}{|l|}{ OPŠTINA GRABOVICA } \\
\hline $\begin{array}{l}\text { Grabovica } \\
\text { parohija Valjevo }\end{array}$ & 710 & 3 & $0,42 \%$ \\
\hline $\begin{array}{l}\text { Jasenica } \\
\text { parohija Valjevo }\end{array}$ & 290 & 8 & $2,76 \%$ \\
\hline $\begin{array}{l}\text { Rađevo Selo } \\
\text { parohija Valjevo }\end{array}$ & 428 & 6 & $1,40 \%$ \\
\hline $\begin{array}{l}\text { Kozličić } \\
\text { parohija Brankovina }\end{array}$ & 261 & 3 & $1,15 \%$ \\
\hline \multicolumn{4}{|l|}{ OPŠTINA BRANKOVINA } \\
\hline $\begin{array}{l}\text { Brankovina } \\
\text { parohija Brankovina }\end{array}$ & 412 & 1 & $0,24 \%$ \\
\hline $\begin{array}{l}\text { Blizonje } \\
\text { parohija Brankovina }\end{array}$ & 272 & 3 & $1,10 \%$ \\
\hline $\begin{array}{l}\text { Babina Luka } \\
\text { parohija Brankovina }\end{array}$ & 723 & 15 & $2,07 \%$ \\
\hline $\begin{array}{l}\text { Zabrdica } \\
\text { parohija Brankovina }\end{array}$ & 614 & 5 & $0,81 \%$ \\
\hline $\begin{array}{l}\text { Joševa } \\
\text { parohija Brankovina }\end{array}$ & 273 & 4 & $1.46 \%$ \\
\hline \multicolumn{4}{|l|}{ OPŠTINA KOTEŠICA } \\
\hline $\begin{array}{l}\text { Kotešica } \\
\text { parohija Brankovina }\end{array}$ & 889 & 16 & $1,80 \%$ \\
\hline $\begin{array}{l}\text { Rabas } \\
\text { parohija Brankovina }\end{array}$ & 177 & 1 & $0,56 \%$ \\
\hline \multicolumn{4}{|l|}{ OPŠTINA POPUČKE } \\
\hline $\begin{array}{l}\text { Popučke } \\
\text { parohija Rabrovica - Divci }\end{array}$ & 1.069 & 6 & $0,56 \%$ \\
\hline \multicolumn{4}{|l|}{ OPŠTINA LOZNICA } \\
\hline $\begin{array}{l}\text { Loznica } \\
\text { parohija Rabrovica - Divci }\end{array}$ & 692 & 8 & $1,16 \%$ \\
\hline $\begin{array}{l}\text { Veselinovac } \\
\text { parohija Rabrovica - Divci }\end{array}$ & 253 & 1 & $0,39 \%$ \\
\hline $\begin{array}{l}\text { Slovac } \\
?\end{array}$ & 278 & $?$ & $?$ \\
\hline
\end{tabular}

${ }^{39}$ Umrli za koje je kao uzrok smrti eksplicitno navedeno ,španska groznica“, ,„spanska bolest“ i „zarazna influenca“, uključujući i umrle u bolnici u Valjevu, za koje je u jeku pandemije po lekarskom nalazu konstatovana smrt usled ,pneumonije“, zatim umrli od „zapaljenja pluća“ u selima parohije u Jovanji i „tifusne groznice“ u selu Balinoviću, koje je jedino iz pričevićke parohije pripadalo Valjevskom srezu (videti napomenu 22). Relativno retki umrli u jeku pandemije u parohijama u čijim knjigama umrlih je korišćen naziv bolesti koji eksplicitno ukazuje na pandemiju, a kojima je kao uzrok smrti upisano „zapaljenje pluća“, nisu uneti u ovu tabelarnu statistiku. 


\begin{tabular}{|c|c|c|c|}
\hline \multicolumn{4}{|l|}{ OPŠTINA LUKAVAC } \\
\hline $\begin{array}{l}\text { Lukavac } \\
\text { parohija Rabrovica - Divci }\end{array}$ & 692 & 0 & $0,00 \%$ \\
\hline $\begin{array}{l}\text { Dupljaj } \\
\text { parohija Rabrovica - Divci }\end{array}$ & 458 & 3 & $0,65 \%$ \\
\hline \multicolumn{4}{|l|}{ OPŠTINA DIVCI } \\
\hline $\begin{array}{l}\text { Divci } \\
\text { parohija Rabrovica-Divci }\end{array}$ & 329 & 2 & $0,61 \%$ \\
\hline $\begin{array}{l}\text { Klanica } \\
\text { parohija Rabrovica - Divci }\end{array}$ & 555 & 0 & $0,00 \%$ \\
\hline \multicolumn{4}{|l|}{ OPŠTINA PETNICA } \\
\hline $\begin{array}{l}\text { Petnica } \\
\text { parohija Petnica }\end{array}$ & 167 & 8 & $4,79 \%$ \\
\hline $\begin{array}{l}\text { Beloševac } \\
\text { parohija Petnica }\end{array}$ & 378 & 6 & $1,59 \%$ \\
\hline $\begin{array}{l}\text { Bujačić } \\
\text { parohija Petnica }\end{array}$ & 238 & 2 & $0,84 \%$ \\
\hline $\begin{array}{l}\text { Klinci } \\
\text { parohija Petnica }\end{array}$ & 348 & 2 & $0,57 \%$ \\
\hline $\begin{array}{l}\text { Žabari } \\
\text { parohija Petnica }\end{array}$ & 414 & 6 & $1,45 \%$ \\
\hline \multicolumn{4}{|l|}{ OPŠTINA JOVANJA } \\
\hline $\begin{array}{l}\text { Paklje } \\
\text { parohija Jovanja }\end{array}$ & 174 & 8 & $4,60 \%$ \\
\hline $\begin{array}{l}\text { Sedlari } \\
\text { parohija Jovanja }\end{array}$ & 502 & 7 & $1,34 \%$ \\
\hline $\begin{array}{l}\text { Zlatarić } \\
\text { parohija Jovanja }\end{array}$ & 879 & 12 & $1,36 \%$ \\
\hline $\begin{array}{l}\text { Balinović } \\
\text { parohija Pričević }\end{array}$ & 233 & 14 & $6,00 \%$ \\
\hline \multicolumn{4}{|l|}{ OPŠTINA DRAČIĆ } \\
\hline $\begin{array}{l}\text { Dračić } \\
\text { parohija Dračić }\end{array}$ & 175 & 2 & $1,14 \%$ \\
\hline $\begin{array}{l}\text { Bačevci } \\
\text { parohija Dračić }\end{array}$ & 719 & 28 & $3,89 \%$ \\
\hline $\begin{array}{l}\text { Belić } \\
\text { parohija Dračić }\end{array}$ & 116 & 2 & $1,72 \%$ \\
\hline $\begin{array}{l}\text { Brangović } \\
\text { parohija Dračić }\end{array}$ & 198 & 10 & $5,05 \%$ \\
\hline $\begin{array}{l}\text { Degurić } \\
\text { parohija Valjevo }\end{array}$ & 255 & 2 & $0,78 \%$ \\
\hline $\begin{array}{l}\text { Kovačice } \\
\text { parohija Dračić }\end{array}$ & 187 & 6 & $3,21 \%$ \\
\hline $\begin{array}{l}\text { Prijezdić } \\
\text { parohija Dračić (i Krčmar) }\end{array}$ & 345 & $\begin{array}{r}11+2= \\
13 \\
\end{array}$ & $3,77 \%$ \\
\hline $\begin{array}{l}\text { Ravnje } \\
\text { parohija Dračić }\end{array}$ & 336 & 7 & $2,08 \%$ \\
\hline $\begin{array}{l}\text { Zarube } \\
\text { parohija Dračić }\end{array}$ & 179 & 7 & $3,91 \%$ \\
\hline \multicolumn{4}{|l|}{ OPŠTINA LESKOVICE } \\
\hline $\begin{array}{l}\text { Leskovice, Gornje i Donje } \\
\text { parohija manastira Ćelije }\end{array}$ & 1.636 & 105 & $6,42 \%$ \\
\hline
\end{tabular}




\begin{tabular}{|c|c|c|c|}
\hline $\begin{array}{l}\text { Bogatić } \\
\text { parohija manastira Ćelije }\end{array}$ & 325 & 16 & $4,92 \%$ \\
\hline \multicolumn{4}{|l|}{ OPŠTINA LELIĆ } \\
\hline $\begin{array}{l}\text { Lelić } \\
\text { parohija manastira Ćelije }\end{array}$ & 789 & 12 & 1,52 \\
\hline $\begin{array}{l}\text { Sandalj } \\
\text { parohija Jovanja }\end{array}$ & 163 & 0 & $0,00 \%$ \\
\hline $\begin{array}{l}\text { Strmna Gora } \\
\text { parohija manastira Ćelije }\end{array}$ & 193 & 13 & $6,74 \%$ \\
\hline $\begin{array}{l}\text { Stubo } \\
\text { parohija Gračanica (i Jovanja) }\end{array}$ & 497 & $\begin{array}{r}32+2= \\
34 \\
\end{array}$ & $6,84 \%$ \\
\hline $\begin{array}{l}\text { Sušica } \\
\text { parohija manastira Ćelije }\end{array}$ & 403 & 10 & $2,48 \%$ \\
\hline \multicolumn{4}{|l|}{ OPŠTINA REBELJ } \\
\hline $\begin{array}{l}\text { Rebelj } \\
\text { parohija manastira Pustinja }\end{array}$ & 494 & 39 & $7,89 \%$ \\
\hline $\begin{array}{l}\text { Brezovica } \\
\text { parohija Gračanica }\end{array}$ & 715 & 65 & $9,09 \%$ \\
\hline $\begin{array}{l}\text { Vujinovača } \\
\text { parohija manastira Pustinja }\end{array}$ & 360 & 12 & $3,33 \%$ \\
\hline $\begin{array}{l}\text { Kunice } \\
\text { parohija Gračanica }\end{array}$ & 131 & 6 & $4,58 \%$ \\
\hline $\begin{array}{l}\text { Rovni } \\
\text { parohija Gračanica }\end{array}$ & 259 & 16 & $6,01 \%$ \\
\hline $\begin{array}{l}\text { Sovač } \\
\text { parohija manastira Pustinja }\end{array}$ & 365 & 9 & $2,47 \%$ \\
\hline $\begin{array}{l}\text { Tubravić } \\
\text { parohija Gračanica }\end{array}$ & 500 & 32 & $6,44 \%$ \\
\hline \multicolumn{2}{|c|}{$\begin{array}{l}\text { Umrli u Valjevskoj bolnici, iz sela Valjevskog sreza, } \\
\text { van parohije valjevske crkve }\end{array}$} & 15 & \\
\hline $\begin{array}{l}\text { SREZ } \\
\text { SREZ BEZ SLOVCA }\end{array}$ & $\begin{array}{l}27.746 \\
\mathbf{2 7 . 4 6 8}\end{array}$ & 650 & $2,37 \%$ \\
\hline
\end{tabular}

Broj umrlih od španske groznice po naseljima Valjevskog sreza

\section{Zaključna razmatranja}

Kako je do sada predočeno, na osnovu upisa u knjige umrlih na teritoriji Valjevskog sreza od posledica španske groznice umrlo je više od 650 meštana, ${ }^{40}$ odnosno više od 2,37\% stanovništva registrovanog popisom iz 1916. godine, ${ }^{41}$ što bi predstavljalo više od $19,89 \%$ ukupnog direktnog ratnog gubitka. ${ }^{42} \mathrm{Na}$

40 Tabelarna statistika ukazuje na tačno 650 umrlih, ali zbog mogućnosti da iz različitih razloga nisu svi upisani (videti napomenu 32), kao i zbog mogućnosti da su umrli na početku mortalnog udara sa upisanim uzrokom „zapaljenje pluća“ bili žrtve pandemije, realno je pretpostaviti da je ukupan broj žrtava iz Valjevskog sreza veći, pa i znatno, ako se pretpostavi da je španski grip odneo i živote mnogih vojnika koji su umirali pre i posle oslobođenja u različitim bolnicama širom države i nisu upisani u knjige iz svoje parohije.

${ }^{41}$ Uz ograde, zbog mogućih različitih propusta u evidentiranju uzroka smrti, o kojima je prethodno bilo reči.

42 Godine 1910. popisano je 36.867, a 1921. godine 33.600 stanovnika. Љ. Поповић, „Попис становништва Ваљевског округа у I светском рату“. 
teritoriji Valjevskog sreza, koji je delom dolinski, delom sa blagim pobrđem, a delom brdsko-planinski, umrlo je manje stanovništva nego u izrazito brdskoplaninskom Zlatiborskom (oko 5\%) i takođe brdsko-planinskom Kameničkom srezu $(4,25 \%)$. U ravnijim i pristupačnijim delovima sreza umrlo je manje stanovništva nego u delovima sa blagim pobrđem, ali najveća smrtnost je bila $u$ brdsko-planinskim predelima, gde je u pojedinim selima umrlo i $9 \%$ žitelja.

Pre nego što pređemo na dalje izvođenje zaključaka, neophodno je da se naglasi da su na teritoriji Vojvodine, u Šajkaškoj oblasti prvi masovniji smrtni slučajevi registrovani još u septembru $1918 .{ }^{43}$ Međutim, u tim ravničarskim krajevima smrtnost nije bila velika kao u Valjevskom i drugim obrađenim srezovima, budući da je španska groznica u odnosu na ukupan broj preminulih u 1918. godini odnela $18,71 \%$ žrtava, dok je u valjevskom kraju, zavisno od parohije, taj odnos bio od oko $20 \%$, tamo gde su posledice bile najmanje fatalne, pa do $70 \%$.

$\mathrm{Na}$ osnovu do sada iznetog, može se pretpostaviti da je virus španske groznice u valjevskom kraju bio prisutan i tokom prvog, letnjeg talasa, s tim što bolest nije bila fatalna, ali ni prepoznata. Njoj bi eventualno mogle da se pripišu sporadične smrti za čiji uzrok je upisano zapaljenja pluća. Verovatno je i tada, ali i u drugom, mortalnom talasu, španski grip na severnu teritoriju okupirane Srbije stigao iz Austro-Ugarske, ${ }^{44}$ iz pravca Bačke, glavnim komunikacijama, preko Zemuna ${ }^{45}$ do Beograda, gde 6/19. oktobra Natalija Aranđelović upisuje da već uveliko „grdan svet umire“. ${ }^{46}$ Odatle se virus kolskim i železničkim komunikacijama širi po Srbiji i stiže do Valjevskog sreza. Videli smo da je 29. septembra/12. oktobra jedna osoba preminula u Bogovađi, a da pre toga 24 . septembra/7. oktobra počinje masovnije umiranje u divačkoj (rabrovičkoj) parohiji, koja se nalazila ispred Valjeva, na putu ali i železničkoj pruzi ka Beogradu. Odatle se virus širi ka Valjevu, gde masovnije umiranje počinje 7/20. oktobra, a potom iz ovog sreskog i okružnog centra dalje. Do pojedinih sela bolest stiže vrlo brzo, a do drugih posle nekoliko nedelja.

U većini parohija masovno umiranje počinje, igrom slučaja, upravo u vreme dolaska srpskih vojnika u Valjevo (17/30. oktobar). Neosporno je da su prve smrti izazvane pandemijom registrovane pre dolaska oslobodilaca. Zato, imajući u vidu periode inkubacije i razvoja bolesti, koliko god da su oni bili kratki, početak epidemije i prva masovnija umiranja od njenih posledica u vreme stupanja srpske vojske na tlo valjevskog kraja rezultat su prethodnog širenja

43 Живојин Гавриловић, „Пандемија шпанске грознице у Шајкајшкој 1918-1919“, Медицински преглед, бр. 7-8, (1995), 277-280.

${ }^{44} \mathrm{Za}$ razliku od južnih krajeva, gde dolazi iz Grčke, u oslobodilačkom naletu srpske vojske posle proboja Solunskog fronta. Terenska bolnica Timočke divizije sa većim brojem obolelih ostavljena je u Velesu, u koji je srpska vojska ušla jedanaest dana po proboju Solunskog fronta, 26. septembra. A telefonista Drinske divizije Milan Đorđević je prve simptome bolesti osetio desetak dana kasnije, kada se nalazio ispred Leskovca. В. Кривошејев, „Прилог проучавању пандемије...”. Tako je pandemija sa oslobodiocima stigla i do Trstenika. Т. Миленковић, н. д., 161-162.

${ }^{45}$ U Zemunu je tokom oktobra registrovano 300 smrtnih slučajeva. Milorad Radusin, "The Spanish Flu: Part II", 917-922.

${ }^{46}$ Н. Аранђеловић, н. д., 412. 
virusa iz pravca severa, sa teritorije Austro-Ugarske, ali dolazak srpske vojske je doveo do dodatnog razbuktavanja bolesti. Oboleli su oslobodili obolele, a masovni dočeci vojske koja se pobednički vraća sa Solunskog fronta, a potom dolasci na odsustvo i demobilizacija, sigurno su doprineli znatnom povećanju koncentracije virusa, a time i ubrzanom širenju bolesti i ,sabijanju epidemijske krivulje“. Za kratko vreme je oboleo veliki broj ljudi (Petar Bojović u svom telegramu naglašava: ,cela armija i stanovništvo“), što je verovatno dovelo do brzog stvaranja kolektivnog imuniteta i sprečavanja pojave trećeg talasa, ako ne u potpunosti, onda u punoj mortalnoj snazi. Zato tokom prvih meseci 1919. godine nije bilo masovnog umiranja, ali se mestimično uočavaju „džepovi“ i „repovi“ pandemije sa sporadičnim smrtnim slučajevima, verovatno hroničnih bolesnika (tuberkuloza) i osoba sa slabim imunitetom.

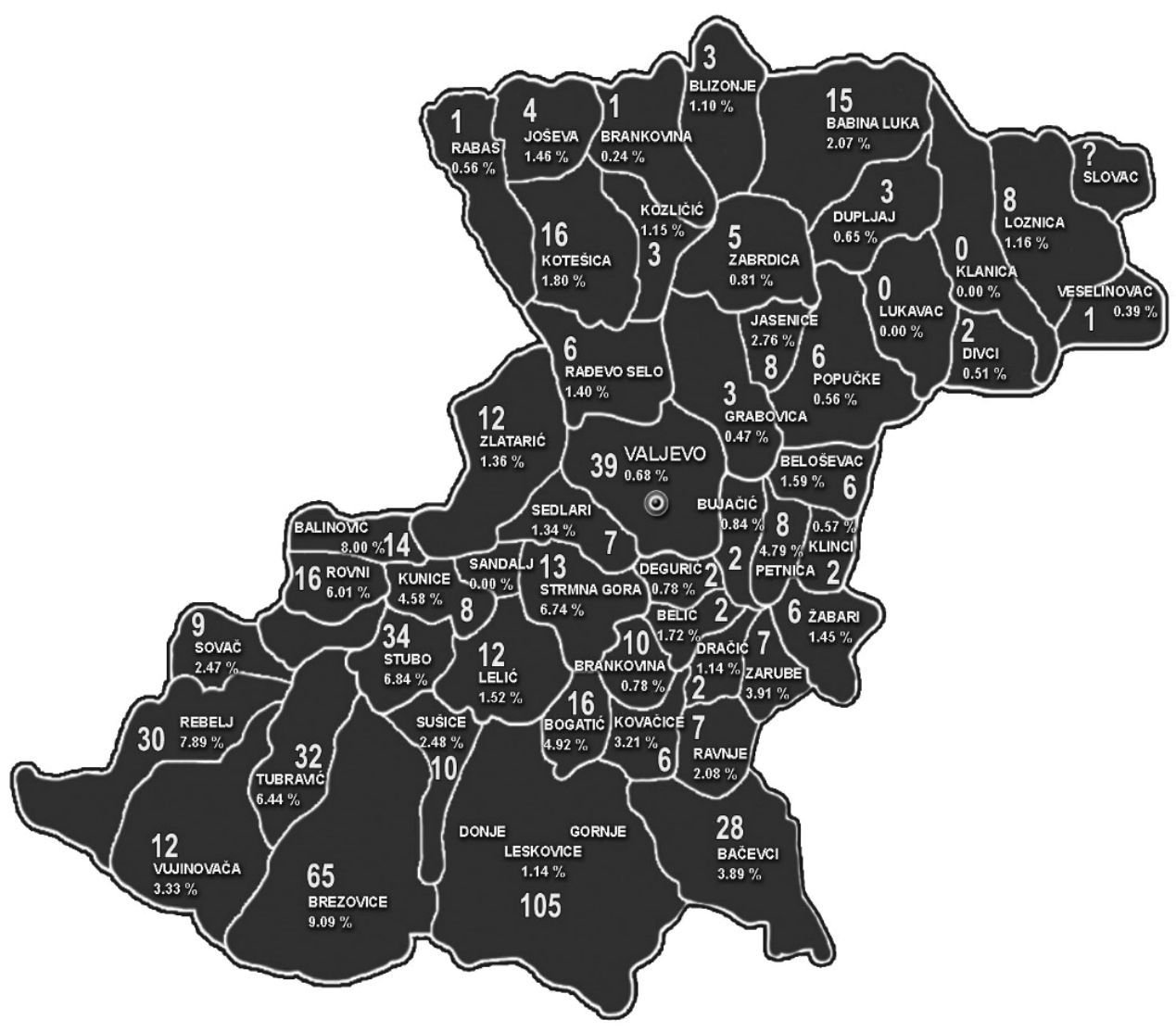

Karta Valjevskog sreza sa označenim brojem umrlih po selima i procentom u odnosu na broj stanovnika po popisu iz 1916. godine (izradio Zoran Mujbegović) 
Kako je u više navrata naglašavano, smrtnost je bila znatno manja u samoj varoši i u ravničarskim predelima, kao i brdskim koji su dobrim putnim komunikacijama bili povezani sa varoši, a kako se udaljavamo u nepristupačnije, zabačenije, brdsko-planinske krajeve, tako i stopa smrtnosti raste i u pojedinim selima dostiže i 9\%. Takva, naizgled paradoksalna, situacija da je smrtnost veća u izolovanim krajevima, sa manjom naseljenošću, na većim nadmorskim visinama i sa slabijim komunikacijama nego u gušće naseljenim predelima mogla bi s jedne strane da se objasni nižim kulturnim nivoom, koji je podrazumevao i nižu zdravstvenu kulturu i higijenske navike. Tu treba razmotriti i specifičnost života u porodičnim zadrugama u ruralnim predelima, sa velikim brojem članova domaćinstva i svojevrsnim polukolektivnim smeštajem, ishranom iz istih posuda, nepoznavanjem zaštitnih mera i dr. S druge strane, stanovništvu zabačenijih brdsko-planinskih krajeva, sa otežanim komunikacijama, u znatno manjoj meri je bila omogućena lekarska pomoć koja je žiteljima varoši i njoj bližih sela bila pristupačnija. A zbog otežanih komunikacija stanovništvo iz zabačenijih ruralnih predela je imalo manje ranijih kontakata sa različitim ljudima, te je bilo u manjoj mogućnosti da se ,prokuži“" i time stekne jači opšti imunitet. Svemu tome treba dodati i da je opšti imunitet stanovništva generalno dodatno oslabljen slabom ishranom usled četvorogodišnjeg života u ratnoj oskudici. 


\section{REFERENCE}

- Aranđelović, Natalija. Dnevnik 1915-1918. Beograd: Istorijski arhiv Beograda, 2018.

- Đenić, Milisav. „Epidemije tifusa i španske groznice na Zlatiboru u vreme Prvog svetskog rata“. Užički zbornik, 14, (1985), 151-164.

- Gavrilović, Živojin. „Pandemija španske groznice u Šajkaškoj 1918-1919“. Medicinski pregled, 7-8, (1995), 277-280.

- Definitivni rezultati popisa stanovništva od 31. januara 1921. Sarajevo: Državna štamparija, 1932

- Krivošejev, Vladimir. Oslobođenje Valjeva u Velikom ratu 30. oktobra 1918. Valjevo: Književni klub Valjeva, 2018.

- Krivošejev, Vladimir. „Prilog proučavanju pandemije španske groznice u selima Valjevskog kraja“. Glasnik Istorijskog arhiva Valjevo, 54, (2020), 61-97.

- Krivošejev, Vladimir. „Smrt u Krčmaru: prilog kvantifikaciji žrtava pandemije španskog gripa 1918. godine“. Etnoantropološki problemi, vol. 15, sv. 2, (2020), 601-626.

- Krivošejev, Vladimir, Jelena Krivošejev i Alen Radosavljević. „Smrtne posledice epidemije španske groznice 1918. godine u Kameničkom srezu valjevskog okruga“, (rad poslat 25. aprila 2020. uredništvu Vojnoistorijskog časopisa; recenzentski prihvaćen; u pripremi za štampu).

- Milenković, Toma. Trstenik i okolina u Prvom svetskom ratu: 1914-1918. Beograd: Institut za savremenu istoriju, 2007.

- Nik, Alfred. „Historiografija vojnog saniteta Jugoslovenskih zemalja, II dio: 1912-1919". Acta historica Medicinae, Pharmaciae, Veterinae, X/1-2, (1969), 219-239.

- Popović, Ljubodrag. „Prilozi za istoriju užičkog kraja u Prvom svetskom ratu: gubici u stanovništvu od 1912-1918“. Užički zbornik, 14, (1985), 137-150.

- Popović, Ljubodrag. „Popis stanovništva Valjevskog okruga u I svetskom ratu“. Glasnik Istorijskog arhiva Valjevo, 34, (2000), 159-170.

- Radusin, Milorad. "The Spanish Flu: Part I: the first wave". Vojnosanitetski pregled, 69, 9, (2012), 812-817.

- Radusin, Milorad. "The Spanish Flu: Part II: the second and third wave". Vojnosanitetski pregled, 69, 10, (2012), 917-922.

- Trajković, Ljubica. Kazivanja o starom Valjevu. Valjevo: privatno izdanje Dragoljuba Trajkovića, 1980. 
VLADIMIR KRIVOŠEJEV, PhD, Research Associate

National Museum of Valjevo

Valjevo, Republic of Serbia

vladimir.krivosejev@gmail.com

\title{
THE CONSEQUENCES OF THE SPANISH FLU PANDEMIC IN VALJEVO COUNTY 1918-1919
}

\begin{abstract}
Summary
The Spanish Flu pandemic that afflicted the entire planet between 1918 and 1919 did not bypass the population in occupied Serbia, nor the soldiers at the Salonica front. It escalated immediately after the breakthrough of the front and culminated in the moments of delight and euphoria that followed the liberation. The purpose of this paper is to point to the possible entry route of the epidemic, the chronology of its development in the Valjevo County, as well as the number of victims it took in each community. The analysis of an almost complete, $100 \%$ sample of church death registers shows that the population started dying at the beginning of October in the lowland areas but that the mortality there was relatively low. The epidemic spread from the plains to the more remote and inaccessible mountain villages, where the mortality rate was very high, so that in some communities more than $9 \%$ of the population died. The epidemic lasted through the end of 1918, while on the territories where the consequences were more widespread, there were noticeably less relapses afterwards. It seems that the population in the remote, inaccessible communities had a more limited access to healthcare facilities in towns and a lower awareness of public hygiene, while limited means of communication made these communities more isolated and thus lowered their herd immunity. These circumstances meant that a significantly higher percentage of rural communities contracted the disease, which in turn contributed to the subsequent buildup of herd immunity.
\end{abstract}

KEYWORDS: Epidemic 1918, Pandemic, Spanish Flu, Spanish Influenza, World War I, Serbia, Valjevo County 